\title{
Tsong kha pa on the Prāsangika View of Time
}

\section{Nemoto Hiroshi}

1 The present paper deals with one of 'the eight difficult issues' (dka' gnas brgyad) which Tsong kha pa (1357-1419) thinks to be brought up by Prāsangika-Mādhyamikas: how to posit the three time-divisions of past, present, and future (dus gsum). In Tsong kha pa's view, Prāsangikas argue that each of the three times is an effective thing (dngos po) and is capable of producing an effect- this is the essential characteristic of their view of the three times. Although over the last decades several studies have been made on the subject, ${ }^{1)}$ it has not been made clear on what grounds Tsong kha pa conceives of the Prāsangika's view of time as differentiated from those of other Buddhist schools.

2 Before moving on to the main task, it is useful to see what are the basic points to note in Tsong kha pa's arguments about the three times. ${ }^{2)}$ To begin with, time is not distinct from the factors which have a temporal existence. That is to say that there is no independent entity called 'past', 'present', or 'future', apart from the factors which are assumed to exist in the three time-periods. This is an understanding of time that Buddhist thinkers have in common. Secondly, the Vaibhāșika view of time that factors exist in all three timeperiods is to be distinguished from the view of time held by other Buddhist schools, Sautrāntika, Yogācāra, and Mādhyamika, which hold that factors exist only in the present. It is to be noted that in discussing the view of time held by these latter schools Tsong kha pa assumes the three times to be defined as follows: the future is a thing's state of having not yet arisen (ma skyes pa); the present is its state of having arisen but having not yet ceased (skyes la ma 'gags pa); and the past is its state of having ceased (zhig pa).

In his assumption there are two points to note. First, in his view the future is not defined as that which will exist later, nor is the past defined as that which existed before. For example, the sprout which existed yesterday is not regarded as a past sprout; instead, the sprout's state of having ceased is said to be the past sprout. Similarly, the sprout which will exist 
tomorrow is not regarded as a future sprout; instead, the sprout's state of having not yet arisen is said to be the future sprout. Secondly, Tsong kha pa uses the word 'present' in a peculiar sense. According to him, the sprout of yesterday satisfies the condition of being the present in the sense that it was in the state of having arisen yesterday. Similarly, the sprout of tomorrow satisfies the condition of being the present in the sense that it will be in the state of having arisen tomorrow. What this shows is that in Tsong kha pa's view the Sautrāntika, Yogācāra, and Mādhyamika schools hold that whatever exists at any particular moment is a present entity, and being present means being existent at any particular moment.

3.1 It is interesting that, in Tsong kha pa's analysis, the view of time held by the Prāsangika school is to be distinguished from that held by the Sautrāntika, Yogācāra, and Svātantrika schools. In his view the former school holds that the past and future are effective things, while the latter three schools hold that they are non-effective things (dngos med) which are existent but incapable of producing their effects.

As we said earlier, the Vaibhāṣika school holds that factors exist as real entities in the three time periods of past, present and future. If the Prāsangika school argues that the past and future are effective things, is its position on the three times identical with that of the Vaibhāșika school? On this question Tsong kha pa makes the following remarks:

[The Prāsangika school's view of time], however, is different from [that of] the Vaibhāșika, because [the Prāsangika school] does not maintain that individual entities such as a sprout are established as [existing] in each of the three temporal periods. According to the theory [of time] advanced by this school [i.e., the Prāsangika school], the three times are as follows: Take, as an example, a sprout. The sprout is the present; its [state of] having ceased is the past; and the sprout's [state of] having not arisen is the future-in general, even if a [main] cause that produces the sprout exists, when there is no complete set of [its subsidiary] causes and conditions, the sprout does not arise at a certain [place and time]. (rTsa she Tik chen, 199a1-2 [Zhol ed.])

What Tsong kha pa means to say is that, in the Vaibhāsika system, a sprout is considered to be existent throughout the three temporal periods; and hence the future and past sprouts are respectively identified with the sprout existing in the future and the one existing in the past. Therefore, it is held by this system that, just as the present sprout, both the future and past sprouts are effective things. In the Prāsangika system, on the other hand, a sprout is considered to exist only in the present time; what are considered to exist in the future and 
past are respectively the sprout's state of having not arisen and its state of having ceased.

It is important here to note the following: In Tsong kha pa's view, while in the Vaibhāṣika system the future, present, and past are considered to be the three distinct states of one and the same entity, in the Prāsangika system they are considered to be the three distinct entities. Moreover, according to him, a sprout's state of having not arisen and its state of having ceased, which the latter school considers respectively as a future sprout and a past sprout, are those which are causally conditioned and which bring about their effects; in other words, they are subject to origination and cessation.

3.2 As Tsong kha pa understands it, the Prāsangika school holds the view that the past is the effective thing which is produced by its cause, and which ceases to exist after having produced its effect. To explain: a sprout's state of having ceased (myu gu zhig pa) arises when the sprout has ceased to exist; and it ceases to exist, bringing about another state of having ceased (myu gu zhig pa zhig pa); the production of the state of having ceased occurs in a sequence. But a question arises. If the sprout's state of having ceased is existent at the moment when it has arisen but has not yet ceased (skyes la ma 'gags pa), why can it be regarded as the past, and not as the present? Tsong kha pa gives the following answer:

Thus, no matter how many things of the same class as the past entity may arise, the [past entity] itself must be posited [as the past] by [taking into consideration the fact that] the entity different [from the past entity] has ceased; and hence, there is a great difference between [the past] and the other two times [i.e., the present and future]. Similarly, no matter how many things of the same class as the future entity may arise, the [future entity] itself must be posited [as the future] only by [taking into consideration the fact that] the entity different [from the future entity] has not yet arisen; and hence, there is a great difference between [the future] and the other two, i.e., the past and present. ( $r$ Tsa she Tik chen, 199a4-6)

The point is that even if a sprout's state of having ceased is in the state of having arisen, it must be described as the past in view of the fact that the sprout, which is different from the state, has ceased. In addition, since the past and present are considered to be mutually exclusive ('gal $b a$ ), the sprout's state of having ceased cannot at the same time be the past and the present. The same thing can be said of a sprout's state of having not yet arisen. Even if such a state of the sprout is in the state of having arisen, it must be described as the future in view of the fact that the sprout, which is different from the state, has not yet arisen. For the same reason as in the state of having ceased, the sprout's state of having not 
yet arisen cannot at the same time be the future and the present. According to Tsong kha pa, this is how the Prāsangika school differentiates the past from the present and future; the future from the present and past.

3.3 It is important to note that, in Tsong kha pa's understanding, the Sautrāntika, Yogācāra, and Svātantrika schools cannot agree with the Prāsañgika school about the characteristics of the future and past. For, according to him, the former schools hold that, because the future and past are what are intrinsically established, they cannot be posited as effective things; whereas the latter holds that, precisely because they are what lacks any intrinsic nature, they can be posited as effective things. Tsong kha pa says:

This way of positing the past and future is not acceptable in [the system which holds that] things are intrinsically established, but it is completely acceptable in the [Prāsangika] system which does not accept even at the conventional level that things have their intrinsic natures. (rTsa she Tik chen, 112a4-5)

In Tsong kha pa's view, the Sautrāntika, Yogācāra, and Svātantrika schools hold that an effective thing is what is intrinsically established (rang gi ngo bos grub pa), and what is intrinsically established is what can be obtained through analytical thinking. Since no effective thing can be obtained through analytic thinking when an entity has not yet arisen or when it has ceased, the future and past are not effective things. On the other hand, the Prāsangika school holds that there is nothing which can be obtained through analytical thinking, for all phenomena are mere nominal designations. It is, however, possible to designate an entity as an effective thing if and only if it is causally conditioned. Since the future and past are dependent on causes, one can designate them as effective things without seeking to obtain them through analytic thinking. This is how this school can posit the future and past as effective things. ${ }^{3 \text { ) }}$

4 As we have seen, the Prāsangika view of time, as Tsong kha pa understands it, differs from those of all other Buddhist schools. First, it differs from the Vaibhāṣika view of time: while Vaibhāșikas assert that such factors as a sprout are existent throughout the three temporal periods, Prāsangikas hold the view that factors are existent only in the present. Secondly, it differs from the view of time shared by Sautrāntikas, Yogācāras, and Svātantrikas: the Prāsangikas, unlike the followers of these three schools, consider the future and past to 
be effective things. Although Tsong kha pa's understanding of the Prāsangika view of time seems to be prima facie realistic, what is important is that he tries to understand the view within the framework of the Prāsangika theory that all phenomena lack an intrinsic nature and that what lacks an intrinsic nature can be regarded as an effective thing. It is in this respect that Tsong kha pha considers the Prāsangika view of time as unique.

\section{Notes}

1 ) See, in particular, Cozort, D. Unique Tenets of the Middle Way Consequence School. Snow Lion. Ithaca. 1998.

2 ) For further details of Tsong kha pa's view on time, see Nemoto, H. "Tsong kha pa on the Three Times: New Light on the Buddhist Theory of Time, "in Logic and Belief in Indian Philosophy. Proceedings of the International Seminar [30 April - 5 May, 2006 Warsaw and Bialowieźa, Poland]. Delhi (Forthcoming).

3 ) For further details of this argument, see $r$ Tsa she Tik chen, 109b6-112a5 (cf. Cozort 1998: 197-209) and dGongs pa rab gsal, 127b2-6, Zhol ed. (cf. Cozort 1998: 190-192).

〈Key Words〉 Tsong kha pa, rTsa she Tik chen, dus gsum, Prāsañika

(Graduate Student, Hiroshima University) 